\title{
KINETIKA REAKSI PADA PROSES PRODUKSI DIETIL ETER DARI ETANOL DENGAN KATALIS H-ZEOLIT
}

\author{
Widayat $^{\left.{ }^{*}\right)}$, Achmad Roesyadi ${ }^{2)}$, dan Muhammad Rachimoellah ${ }^{2)}$ \\ ${ }^{1)}$ Jurusan Teknik Kimia Fakultas Teknik Universitas Diponegoro Semarang \\ Jl. Prof Sudarto SH Tembalang 50275, Telp. (024)7460058; fax. (024)76480675 \\ ${ }^{2)}$ Jurusan Teknik Kimia Fakultas Teknologi Industri Institut Teknologi Sepuluh Nopember \\ Kampus ITS, Keputih, Sukolilo, Surabaya 60111. Telp. (031) 5946240; Fax. (031) 5999282 \\ ${ }^{*}$ Penulis korespondensi: yayat_99@yahoo.com
}

\begin{abstract} under surface reaction is shown by

$$
\begin{aligned}
& \mathrm{r}_{\mathrm{A} 1}=-\frac{4.266 \mathrm{e}^{-\frac{30,869.1}{R T}} \mathrm{P}_{\mathrm{B}}}{\left(1+20.756 \mathrm{P}_{\mathrm{A}}+90.357 \mathrm{P}_{\mathrm{B}}+115.613 \mathrm{P}_{\mathrm{C}}+21.088 \mathrm{P}_{\mathrm{D}}+119.95 \mathrm{P}_{\mathrm{I}}\right)} \\
& \mathrm{r}_{\mathrm{A} 2}=-\frac{205.3086 \mathrm{e}^{-\frac{31,287.8}{R T}}}{\left(1+20.756 \mathrm{P}_{\mathrm{A}}+90.357 \mathrm{P}_{\mathrm{B}}+115.613 \mathrm{P}_{\mathrm{C}}+21.088 \mathrm{P}_{\mathrm{D}}+119.95 \mathrm{P}_{\mathrm{I}}\right)} \mathrm{P}_{\mathrm{D}}
\end{aligned}
$$
\end{abstract}

KINETIC STUDY OF DIETHYL ETHER PRODUCTION PROCESS FROM ETHANOL USING H-ZEOLITE CATALYST. DiEthyl Ether is produced by using ethanol dehydration process. The objective of this research was to study the reaction kinetic of ethanol dehydration process by $\mathrm{H}$-zeolite catalyst from natural zeolite. The $\mathrm{H}$-zeolite catalyst was prepared by dealumination, calcination, impregnation with $\mathrm{Al}$ and reduction processes. DiEthyl Ether production was produced by using adsorption-catalytic reaction. The kinetic study was did with MATLAB software. Kinetic model of ethanol dehydration processes into DiEthyl Ether and ethylene with $\mathrm{H}$ zeolite catalyst and ethanol feed concentration among 85-95\% and temperature between $140-240^{\circ} \mathrm{C}$

Key words: DiEthyl Ether; ethanol conversion; kinetic reaction; zeolite catalyst

\begin{abstract}
Abstrak
DiEtil Eter diproduksi dari etanol dengan proses dehidrasi. Penelitian ini bertujuan untuk mempelajari kinetika reaksi proses dehidrasi etanol dengan katalis $\mathrm{H}$-zeolit. Katalis $\mathrm{H}$-zeolit disintesis dengan proses dealuminasi dan kalsinasi dan impregnasi dengan logam Al dan proses reduksi dan kalsinasi. Proses produksi DiEtil Eter dilaksanakan dengan proses adsorpsi dan reaksi katalitik sedangkan proses studi kinetika reaksi menggunakan pendekatan Langmuir-Hinshelwood. Proses analisis kinetika reaksi menggunakan perangkat lunak MATLAB. Model kinetika reaksi proses dehidrasi etanol menjadi DiEtil Eter dan etilen dengan katalis H-zeolit pada konsentrasi umpan etanol $85-95 \%$ dan rentang temperatur $140-240^{\circ} \mathrm{C}$, dimana reaksi permukaan yang mengontrol reaksi global adalah

$$
\begin{aligned}
& \mathrm{r}_{\mathrm{A} 1}=-\frac{4,266 \mathrm{e}^{-\frac{30.869,1}{R T}} \mathrm{P}_{\mathrm{B}}}{\left(1+20,756 \mathrm{P}_{\mathrm{A}}+90,357 \mathrm{P}_{\mathrm{B}}+115,613 \mathrm{P}_{\mathrm{C}}+21,088 \mathrm{P}_{\mathrm{D}}+119,95 \mathrm{P}_{\mathrm{I}}\right)} \\
& \mathrm{r}_{\mathrm{A} 2}=-\frac{205,3086 \mathrm{e}^{-\frac{31.287,8}{R T}}}{\left(1+20,756 \mathrm{P}_{\mathrm{A}}+90,357 \mathrm{P}_{\mathrm{B}}+115,613 \mathrm{P}_{\mathrm{C}}+21,088 \mathrm{P}_{\mathrm{D}}+119,95 \mathrm{P}_{\mathrm{I}}\right)} \mathrm{P}_{\mathrm{D}}
\end{aligned}
$$
\end{abstract}

Kata kunci: DiEtil Eter; konversi etanol; kinetika reaksi; katalis zeolit

\section{PENDAHULUAN}

DiEtil Eter merupakan salah satu dari eter komersial yang paling penting. Hal ini disebabkan DiEtil Eter memiliki nilai ekonomis yang sangat tinggi. Di bidang industri, DiEtil Eter banyak digunakan sebagai bahan pelarut untuk melakukan reaksi-reaksi organik dan memisahkan senyawa organik dari sumber alamnya. Penggunaan sebagai 
pelarut diantaranya untuk pelarut minyak, lemak, getah, resin, mikroselolosa, parfum, alkaloid, dan sebagian kecil dipakai dalam industri butadiena. Di bidang kedokteran, DiEtil Eter sangat identik dengan bahan anestesi (Ullmann, 1987). DiEtil Eter juga dapat digunakan sebagai bahan bakar baik sebagai campuran maupun komponen murninya. DiEtil Eter dicampur dengan etanol dapat mengatasi kekurangan bahan bakar etanol (Kitto Borsa, 1998).

DiEtil Eter dapat diproduksi dari reaksi dehidrasi etanol dengan menggunakan katalis homogen maupun heterogen (Ullmann, 1987). Katalis telah digunakan secara komersial selama lebih dari satu abad dari proses kontak untuk asam sulfat yang digunakan tahun 1800-an hingga proses FCC (Fluid Catalytic Cracking) terbaru untuk perengkahan petrokimia (Zablouka dkk., 2011). Untuk reaksi katalitik, perkembangan katalis yang efektif adalah langkah paling dasar dan kritis. Demikian juga dengan mekanisme dan kinetika rekasi merupakan parameter yang sangat penting dalam menjelaskan reaksi kimia dan perancang reaktor.

De Boer dkk., (1967) adalah orang yang pertama mempelajari kinetika reaksi proses dehidrasi etanol dengan katalis alumina. Hasil penelitian menunjukkan bahwa pembentukan Di Etil Eter terjadi dengan mekanisme reaksi Rideal Eley dan LangmuirHinshlewood terjadi secara simultan. Golay dkk., (1999) mempelajari pengaruh perbandingan $\mathrm{Mg} / \mathrm{Al}$ terhadap reaksi dehidrasi etanol, dimana pada perbandingan $\mathrm{Mg} / \mathrm{Al}$ 2,5\% diperoleh yield Di Etil Eter yang maksimum. Haber dkk, (2002) mencoba dengan katalis $\mathrm{K}_{x} \mathrm{H}_{3}-x \mathrm{PW}_{12} \mathrm{O}_{40}$ dan $\mathrm{Ag}_{x} \mathrm{H}_{3}-x \mathrm{PW}_{12} \mathrm{O}_{40}$. Zeolit jenis modernite juga telah digunakan sebagai katalis oleh Takahara, dkk, (2005) sedangkan Varisli, dkk (2007) menggunakan katalis heteropolyacid. Widayat dan Satriadi (2008) telah memproduksi DiEtil Eter dengan menggunakan katalis asam sulfat dan proses reaktif distilasi. Widayat dkk. (2009, 2010) mengembangkan katalis $\mathrm{H}$-zeolit dengan bahan baku zeolit alam. Katalis yang dihasilkan mampu untuk menkatalisis proses dehidrasi bioetanol menjadi DiEtil Eter. Kelebihan dari proses ini adalah bahan baku etanol masih mengandung air, padahal reaksi dehidrasi merupakan reaksi pelepasan air. Widayat dkk. (2011) juga telah meningkatkan proses dehidrasi bioetanol dengan menggunakan proses adsorpsi yang dilanjutkan dengan dengan reaksi. Proses ini juga dapat meningkatkan laju reaksi pembentukan DiEtil Eter.

Namun hingga saat ini belum ada yang mempelajari kinetika reaksi proses dehidrasi etanol dengan katalis $\mathrm{H}$-Zeolite, oleh karena penelitian ini bertujuan untuk mempelajari kinetika reaksi proses dehidrasi etanol menjadi dietil eter dengan katalis $\mathrm{H}$ Zeolit.

\section{Analisis Model Kinetika}

Reaksi dehidrasi etanol menghasilkan dua senyawa yaitu DiEtil Eter dan etilen mengikuti persamaan 1 dan 2. Untuk memudahkan dalam penyusunan model kinetika reaksi, dimisalkan etanol sebagai A, DiEtil Eter sebagai B, air sebagai C dan etilen sebagai D. Sehingga reaksi yang terjadi dapat ditulis sebagai berikut;

$$
\begin{aligned}
2 \mathrm{C}_{2} \mathrm{H}_{5} \mathrm{OH} & \rightleftarrows \mathrm{C}_{2} \mathrm{H}_{5} \mathrm{OC}_{2} \mathrm{H}_{5}+\mathrm{H}_{2} \mathrm{O} \\
2 \mathrm{~A} & \rightleftarrows \mathrm{B}+\mathrm{C} \\
\mathrm{C}_{2} \mathrm{H}_{5} \mathrm{OH} & \rightleftarrows \mathrm{C}_{2} \mathrm{H}_{4}+\mathrm{H}_{2} \mathrm{O} \\
\mathrm{A} & \rightleftarrows \mathrm{D}+\mathrm{C}
\end{aligned}
$$

Mekanisme reaksi menurut LangmuirHonshelwood, jika diterapkan pada reaksi pembentukan DiEtil Eter dan etilen dapat diperoleh 3 pasang model kinetika reaksi untuk reaksi pembentukan DiEtil Eter dan pembentukan etilen. Adapun model-model kinetika tersebut disajikan dalam Tabel 1 berikut ini.

Tabel 1. Model kinetika reaksi pembentukan DiEtil Eter dan etilen berdasarkan tahap reaksinya

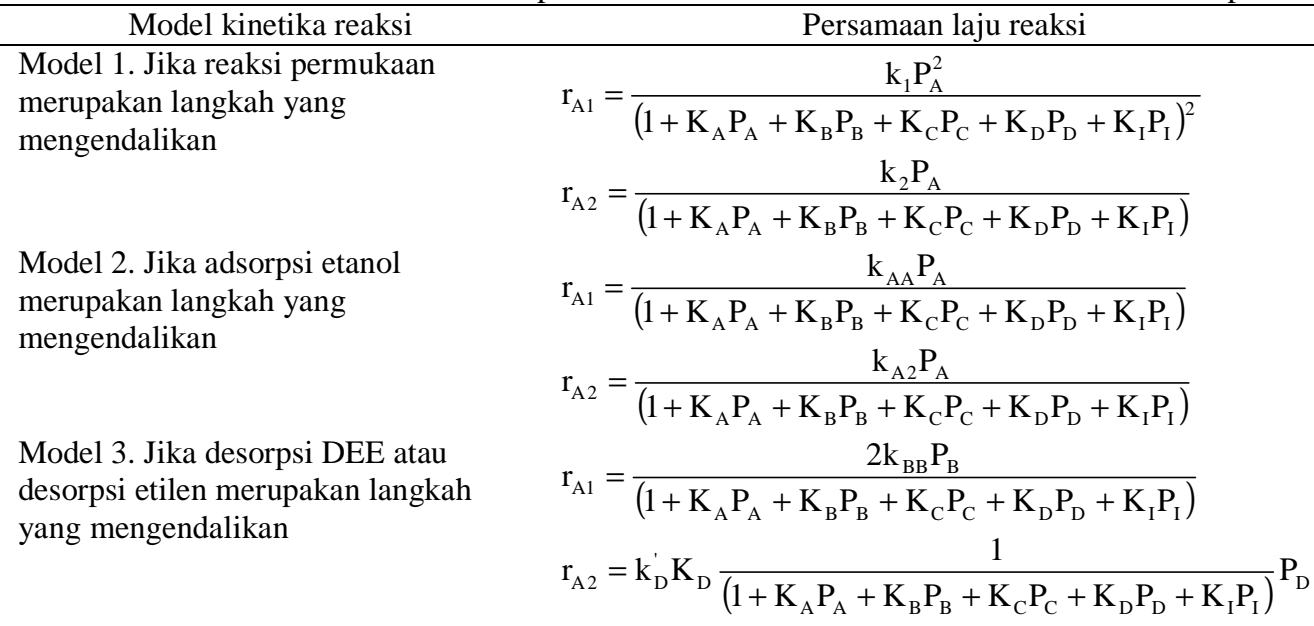


Proses komputasi menggunakan persamaan persamaan Arhenius dengan konstanta kecepatan reaksi :

$$
\mathrm{k}=\mathrm{Ae} \mathrm{e}^{-\mathrm{E}_{\mathrm{A}} / \mathrm{RT}}
$$

Elemen volume reaktor unggun tetap dengan panjang $\Delta Z$ ditunjukkan dalam Gambar 1.

Kecepatan masuk pada titik $\mathrm{Z}=\mathrm{F}_{\mathrm{A} 0}\left(1-\mathrm{x}_{\mathrm{A}}\right)$

Kecepatan A ke luar pada titik $\mathrm{Z}+\Delta \mathrm{Z}=\mathrm{F}_{\mathrm{A} 0}\left\{1-\left(\mathrm{x}_{\mathrm{A}}+\Delta \mathrm{x}_{\mathrm{A}}\right)\right\}$ Kecepatan A bereaksi $=\overline{\mathrm{r}_{\mathrm{A}}} \Delta \mathrm{W}$

Kecepatan akumulasi $\mathrm{A}=0$

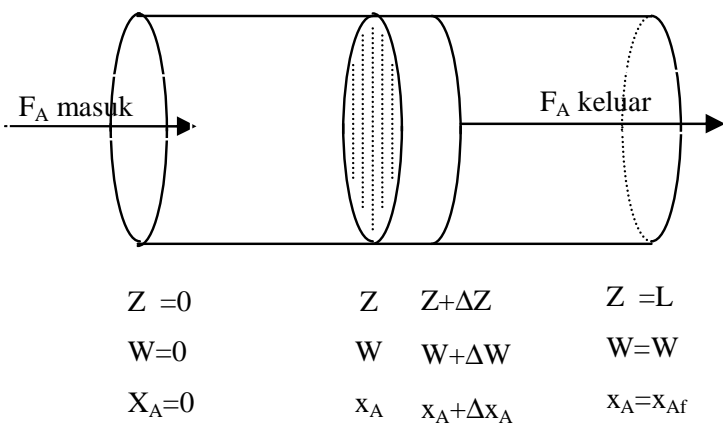

Gambar 1. Elemen volume reaktor unggun tetap

Persamaan neraca massa sebagai berikut :

$$
\mathrm{F}_{\mathrm{A} 0}\left(1-\mathrm{x}_{\mathrm{A}}\right)-\mathrm{F}_{\mathrm{A} 0}\left\{1-\left(\mathrm{x}_{\mathrm{A}}+\Delta \mathrm{x}_{\mathrm{A}}\right)\right\}-\overline{\mathrm{r}_{\mathrm{A}}} \Delta \mathrm{W}=0
$$

Dengan $\Delta \mathrm{x}_{\mathrm{A}}$ dan $\Delta \mathrm{W}$ mendekati nol maka :

$$
\frac{\mathrm{dW}}{\mathrm{F}_{\mathrm{A} 0}}=\frac{\mathrm{dx}_{\mathrm{A}}}{\mathrm{r}_{\mathrm{A}}}
$$

kondisi batas :

$\mathrm{W}=0 ; \quad \mathrm{x}_{\mathrm{A}}=0 \quad$ dan $\quad \mathrm{W}=\mathrm{W} ; \quad \mathrm{x}_{\mathrm{A}}=\mathrm{x}_{\mathrm{Af}}$

Penyelesaian dari persamaan diferensial (14) dengan kondisi batasnya adalah :

$$
\frac{\mathrm{W}}{\mathrm{F}_{\mathrm{A} 0}}=\int_{\mathrm{x}_{\mathrm{A} 0}}^{\mathrm{x}_{\mathrm{Af}}} \frac{\mathrm{dx}_{\mathrm{A}}}{\mathrm{r}_{\mathrm{A}}}
$$

Persamaan 15 dapat ditulis menjadi :

$$
\frac{\mathrm{W}}{\mathrm{F}_{\mathrm{A} 0}}=\int_{\mathrm{x}_{\mathrm{A} 0}}^{\mathrm{x}_{\mathrm{A}}} \frac{\mathrm{dx}_{\mathrm{A}}}{-\mathrm{r}_{\mathrm{A}}}=\frac{1}{\left(-\mathrm{r}_{\mathrm{A}}\right)_{\text {rata-rata }}} \int_{\mathrm{x}_{\mathrm{A} 0}}^{\mathrm{x}_{\mathrm{A}}} \mathrm{d} \mathrm{x}_{\mathrm{A}}=\frac{\mathrm{x}_{\mathrm{A}}-\mathrm{x}_{\mathrm{A} 0}}{\left(-\mathrm{r}_{\mathrm{A}}\right)_{\text {rata-rata }}}(16)
$$

Laju reaksi rata-ratanya adalah :

$$
\left(-r_{\mathrm{A}}\right)_{\text {rata-rata }}=-\mathrm{r}_{\mathrm{A}}^{\prime}=\frac{\left(\mathrm{x}_{\mathrm{A}}-\mathrm{x}_{\mathrm{A} 0}\right) \mathrm{F}_{\mathrm{A} 0}}{\mathrm{~W}}
$$

Hubungan antara konversi etanol $\left(\mathrm{x}_{\mathrm{A}}\right)$ terhadap tekanan reaktan dan produk serta tekanan total $(\mathrm{P})$ yang berperan dalam reaksi pembentukan DEE dan etilen dijabarkan sebagai berikut :

$$
\begin{gathered}
\mathrm{P}_{\mathrm{A}}=\frac{\mathrm{F}_{\mathrm{A} 0}\left(1-\mathrm{x}_{\mathrm{A}}\right)}{\mathrm{F}+\mathrm{F}_{\mathrm{A} 0} \mathrm{x}_{\mathrm{A} 2}} \mathrm{P} \\
\mathrm{P}_{\mathrm{B}}=\frac{\frac{1}{2} \mathrm{~F}_{\mathrm{A} 0} \mathrm{x}_{\mathrm{A} 2}}{\mathrm{~F}+\mathrm{F}_{\mathrm{A} 0} \mathrm{x}_{\mathrm{A} 2}} \mathrm{P} \\
\mathrm{P}_{\mathrm{C}}=\frac{\frac{1}{2} \mathrm{~F}_{\mathrm{A} 0} \mathrm{x}_{\mathrm{A} 1}+\mathrm{F}_{\mathrm{A} 0} \mathrm{x}_{\mathrm{A} 2}}{\mathrm{~F}+\mathrm{F}_{\mathrm{A} 0} \mathrm{x}_{\mathrm{A} 2}} \mathrm{P} \\
\mathrm{P}_{\mathrm{D}}=\frac{\mathrm{F}_{\mathrm{A} 0} \mathrm{x}_{\mathrm{A} 2}}{\mathrm{~F}+\mathrm{F}_{\mathrm{A} 0} \mathrm{x}_{\mathrm{A} 2}} \mathrm{P}
\end{gathered}
$$

$$
\mathrm{P}_{\mathrm{I}}=\frac{\mathrm{F}_{\mathrm{I} 0}}{\mathrm{~F}+\mathrm{F}_{\mathrm{A} 0} \mathrm{x}_{\mathrm{A} 2}} \mathrm{P}
$$

Konstanta-konstanta dalam model kinetika reaksi dievaluasi berdasarkan persamaan 5-10 di atas. Sebagai fungsi obyektif dari optimasi adalah jumlah $\left(\mathrm{r}_{\text {Adata }}-\mathrm{r}_{\mathrm{A} \text { model }}\right)^{2}$ yang minimum, yang secara matematis dapat diungkapkan sebagai berikut :

$$
\mathrm{SSE}=\sum_{1}^{\mathrm{n}}\left(\mathrm{r}_{\text {Adata }}-\mathrm{r}_{\text {A model }}\right)^{2}
$$

Jika persamaan terakhir diterapkan untuk setiap model yang diuji, maka fungsi obyektif dapat diekspresikan ke dalam 3 persamaan SSE sebagai berikut :

Model 1.

$\mathrm{SSE}=\sum_{1}^{\mathrm{n}}\left(\mathrm{r}_{\text {Adata }}-\mathrm{r}_{\text {A model }}\right)^{2}=\mathrm{f}\left(\mathrm{k}_{1}, \mathrm{k}_{2}, \mathrm{~K}_{\mathrm{A}}, \mathrm{K}_{\mathrm{B}}, \mathrm{K}_{\mathrm{C}}, \mathrm{K}_{\mathrm{D}}, \mathrm{K}_{\mathrm{I}}\right)$

Model 2.

$\mathrm{SSE}=\sum_{1}^{\mathrm{n}}\left(\mathrm{r}_{\text {Adata }}-\mathrm{r}_{\text {A model }}\right)^{2}=\mathrm{f}\left(\mathrm{k}_{\mathrm{AA}}, \mathrm{k}_{\mathrm{A} 2}, \mathrm{~K}_{1}, \mathrm{~K}_{\mathrm{B}}, \mathrm{K}_{\mathrm{C}}, \mathrm{K}_{\mathrm{D}}, \mathrm{K}_{\mathrm{I}}\right)$

Model 3.

$\mathrm{SSE}=\sum_{1}^{\mathrm{n}}\left(\mathrm{r}_{\text {Adata }}-\mathrm{r}_{\text {A mod el }}\right)^{2}=\mathrm{f}\left(\mathrm{k}_{\mathrm{D}}^{\prime}, \mathrm{k}_{\mathrm{BB}}, \mathrm{K}_{\mathrm{A}}, \mathrm{K}_{\mathrm{B}}, \mathrm{K}_{3}, \mathrm{~K}_{\mathrm{D}}, \mathrm{K}_{\mathrm{I}}\right)$

\section{METODE PENELITIAN \\ Alat dan Bahan}

Bahan baku utama dalam penelitian ini adalah zeolit alam, yang diperoleh dari Kecamatan Wonosari Kabupaten Gunung Kidul. Zeolit alam pada awalnya dilakukan analisa terhadap komposisi penyusunnya, kadar air dan bentuk kristalitasnya. Bahan kimia yang digunakan adalah $\mathrm{HCl}$ teknis, $\mathrm{AgNO}_{3}$ p.a (Merck) dan aquadest. Perak nitrat dalam penelitian digunakan sebagai indikator pada saat proses pencucian.

Untuk proses dealuminasi digunakan alat labu leher tiga dilengkapi dengan pemanas air, pengadukan, pendingin balik dan temperatur. Alat untuk kalsinasi digunakan furnace yang berbentuk tabung dan dilengkapi tabung nitrogen, rotameter dengan sistem pemipaan untuk aliran nitrogen. Untuk menampung katalis digunakan nucelle yang berdiameter $1 / 2$ inci dan terbuat dari bahan quartz. Peralatan untuk proses kalsinasi, juga dapat digunakan untuk proses reduksi. Pada proses reduksi ditambahkan aliran gas hidrogen. Peralatan proses produksi dengan proses adsorpsireaksi katalitik terdiri unit adsorpsi dan unit reaksi. Unit adsorpsi menggunakan unggun zeolit molekuler sieve dan unit reaksi dengan unggun katalis zeolit. Rangkaian untuk proses produksi DiEtil Eter terdiri dari tangki penguapan etanol/vaporizer, reaktor unggun tetap dengan diameter $1 / 2$ inci, kondensor, pemanas/heater, dan pengendali temperature serta unit adsorpsi. Rangkaian peralatan seperti disajikan dalam Gambar 2. Peralatan yang digunakan terdiri tangki penguapan yang dihubungkan dengan aliran gas inert/nitrogen. Aliran nitrogen dilengkapi dengan 
rotameter dan kerangan untuk mengatur laju alir gas nitrogen.

\section{Prosedur Pembuatan Katalis}

Proses aktivasi katalis yang dilakukan adalah dengan perlakuan kimia (asam klorida), pencucian, pengeringan dan proses kalsinasi. Aktivasi secara kimia bertujuan untuk membersihkan permukaan pori, membuang senyawa pengotor, mengatur kembali letak atom yang dipertukarkan. Prinsip aktivasi secara kimiawi ini adalah penambahan pereaksi tertentu sehingga didapatkan pori-pori zeolit yang bersih (aktif) proses aktivasi zeolit juga ditujukan untuk memodifikasi sifat-sifat dari zeolit, seperti luas permukaan dan keasaman. Luas permukaan dan keasaman yang meningkat akan menyebabkan aktivitas katalitik dari zeolit meningkat (Widayat dkk., (2010). Proses yang digunakan dalam penelitian ini adalah mengacu pada Rachwalik dkk., (2005), Boveri dkk., (2006) dan Widayat dkk., (2009, 2010). Proses dilakukan modifikasi dengan pengembanan logam alumonium.

Proses perlakuan kimia/dealuminasi menggunakan larutan asam klorida $4 \mathrm{M}$ dengan komposisi umpan katalis zeolit alam 1 gram itambahkan $20 \mathrm{ml}$ larutan asam klorida $4 \mathrm{M}$. Proses dilangsungkan pada temperatur refluk. Proses kalsinasi menggunakan nucelle/crusibel yang diletakkan di dalam furnace. Katalis yang telah dicuci dan dikeringkan ditaruh dalam crusibel dan dipanaskan pada temperatur $500^{\circ} \mathrm{C}$ dan dialiri gas nitrogen dengan laju $500 \mathrm{~mL} / \mathrm{menit}$. Proses dilangsungkan selama 5 jam. Setelah waktu tercapai, furnace didinginkan dan katalis dikeluarkan untuk dianalisa karakteristiknya dan uji katalitik.

Untuk proses pembuatan katalis dengan impregnasi, katalis H-zeolit diimpregnasi dengan larutan $\mathrm{Al}_{2}\left(\mathrm{SO}_{4}\right)_{3}$ yang dilakukan sebelum proses kalsinasi. Impregnasi katalis dilakukan dengan melarutkan $\mathrm{Al}_{2}\left(\mathrm{SO}_{4}\right)_{3}$ sebanyak $1 \%$ massa katalis $\mathrm{H}$ zeolit ke dalam aquadest hingga larut sempurna lalu katalis H-zeolit dimasukkan ke dalam larutan $\mathrm{Al}_{2}\left(\mathrm{SO}_{4}\right)_{3}$ dan diaduk selama 30 menit. Katalis zeolit selanjutnya disaring dengan kertas saring. Katalis $\mathrm{H}-$ zeolit dipanaskan dalam oven selama 2 jam dalam suhu $110^{\circ} \mathrm{C}$. Kemudian dikalsinasi dengan cara katalis zeolit dimasukkan ke dalam crusible dan diletakkan dalam furnace. Gas nitrogen ke dalam furnace untuk mencegah aliran udara. Furnace dipanaskan pada suhu $500^{\circ} \mathrm{C}$ selama 5 jam. Gas nitrogen dan hidrogen dialirkan ke dalam furnace dengan perbandingan 3:1. Furnace dipanaskan pada suhu $350^{\circ} \mathrm{C}$ selama 4 jam. Furnace didinginkan hingga suhu $50^{\circ} \mathrm{C}$ di dalam furnace.

\section{Metode Analisis}

Analisis produk dietil eter dilakukan di Laboratorium Kimia Analisa Politeknik Negeri Malang, dengan alat kromatografi gas. Alat kromatografi gas menggunakan merk HP 5890 dengan kolom MS 5A dan dektektor TCD (Temperature Conductivity Detector). Proses analisa menggunakan gas pembawa/carrier gas helium dengan laju alir 20 $\mathrm{ml} / \mathrm{menit}$, temperatur kolom $125-250^{\circ} \mathrm{C}$ dan temperatur detektor $275^{\circ} \mathrm{C}$. Komponen yang dianalisa adalah DiEtil Eter, etanol, air, dan metanol.

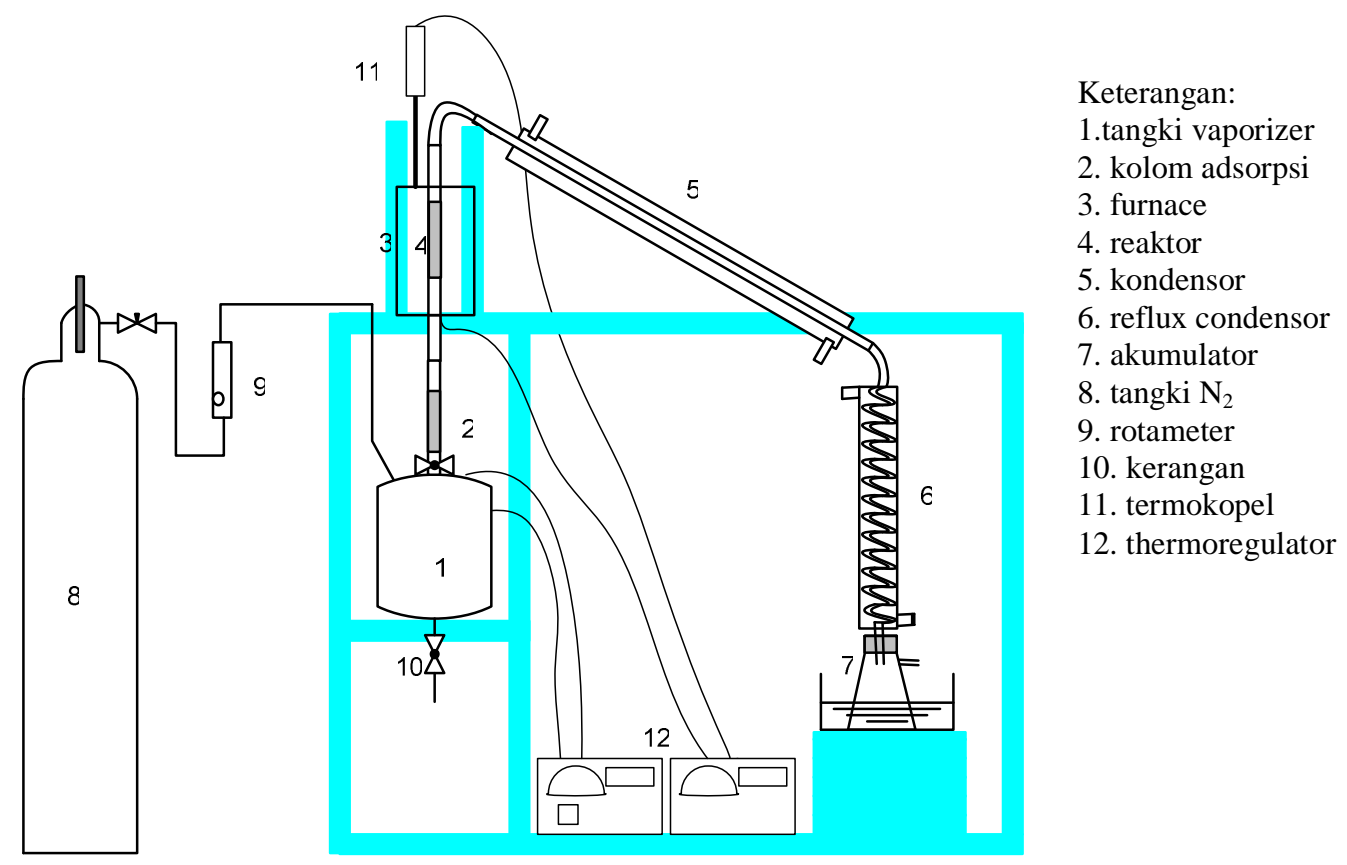

Gambar 2. Rangkaian peralatan untuk proses produksi DiEtil Eter dengan proses adsorpsi-reaksi katalitik 


\section{Proses Simulasi}

Nilai fraksi mol masing-masing komponen, digunakan untuk menghitung tekanan parsial baik keluar maupun masuk reaktor yaitu dengan menggunakan Persamaan 18-22. Hasil perhitungan selanjutnya disajikan dalam bentuk Tabel 2. Data-data laju reaksi total $\left(-\mathrm{r}_{\mathrm{A}}\right)$, tekanan parsial masing-masing komponen sebagai input dalam analisis kinetika reaksi.

Langkah pertama dalam proses simulasi adalah menebak konstanta-konnstanta yang tidak diketahui dalam Persamaan 5-10. Nilai tebakan awal dan datadata pada Tabel 2 digunakan untuk perhitungan laju reaksi berdasarkan Persamaan 5-10. Hasil perhitungan dari model tersebut akan digunakan untuk menghitung fungsi obyektif, dimana laju reaksi reaksi hasil perhitungan dibandingkan dengan laju reaksi hasil percobaan. Nilai-nilai yang akan dicari dalam fungsi obyektif pada Persamaan 26-28. Proses pencarian dilanjutkan sampai jumlah selisih kwadrat (Sum Square error/SSE) menjadi paling kecil/tidak berubah lagi. Jika belum tercapai, maka program akan melakukan perhitungan ulang dengan merubah nilai tebakan. Perhitungan simulasi laju reaksi akan berhenti jika nilai dari fungsi obyektif sudah cukup kecil.
Proses simulasi dengan menggunakan perangkat lunak MATLAB 7, dimana menggunakan fasilitas pencari nilai optimum yaitu fmincon. Hasil simulasi untuk setiap model dibandingkan nilai $\mathrm{f}(\mathrm{x})$ nya /fungsi obyektif dan dipilih nilai yang terkecil. Fungsi obyektif pada kegiatan ini merupakan selisih kwadrat dari laju reaksi etanol hasil eksperimen dengan perhitungan model kinetika. Semakin kecil nilai $f(x)$ maka semakin valid model kinetikanya. Hal ini menunjukkan bahwa data-data reaksi semakin mendekati dengan hasil pemodelan matematika. Pengambilan data laju reaksi etanol dilakukan variasi konsentrasi awal etanol yaitu 85\%, 90\% dan 95\% (berat).

Laju reaksi eksperimen dan laju reaksi model dievalusi nilai \%kesalahan masing-masing dan \%kesalahan rata-rata dengan persamaan 27-28 berikut;

$$
\begin{gathered}
\text { \% kesalahan (i) }=\frac{\mathrm{r}_{\mathrm{Amodel}(\mathrm{i})}-\mathrm{r}_{\mathrm{Apercobaan}(\mathrm{i})}}{\mathrm{r}_{\mathrm{Apercobaan}(\mathrm{i})}} \times 100 \% \\
\% \text { kesalahan rata }- \text { rata }=\frac{\sum \frac{\left|\mathrm{r}_{\mathrm{Amodel}(\mathrm{i})}-\mathrm{r}_{\text {Apercobaan (i) }}\right|}{\mathrm{r}_{\text {Apercobaan }(\mathrm{i})}}}{\mathrm{n}}
\end{gathered}
$$

Tabel 2. Hasil analisis tekanan keluaran reaktor masing-masing komponen

\begin{tabular}{cccccc}
\hline $\mathrm{T}(\mathrm{K})$ & po $\mathrm{C}_{2} \mathrm{H}_{5} \mathrm{OH}$ & po DEE & ${\text { po } \mathrm{C}_{2} \mathrm{H}_{4}}$ & po $\mathrm{H}_{2} \mathrm{O}$ & po $\mathrm{N}_{2}$ \\
\hline 413,0 & 0,0697 & 0,3122 & 0,0025 & 0,3412 & 0,2743 \\
433,0 & 0,0682 & 0,3093 & 0,0073 & 0,3430 & 0,2723 \\
453,0 & 0,0656 & 0,3253 & 0,0078 & 0,3605 & 0,2408 \\
473,0 & 0,0608 & 0,3133 & 0,0084 & 0,3480 & 0,2694 \\
493,0 & 0,0581 & 0,3284 & 0,0103 & 0,3660 & 0,2372 \\
513,0 & 0,0489 & 0,3293 & 0,0116 & 0,3677 & 0,2426 \\
413,0 & 0,0814 & 0,2247 & 0,0033 & 0,2928 & 0,3979 \\
433,0 & 0,0581 & 0,2292 & 0,0046 & 0,2950 & 0,4132 \\
453,0 & 0,0595 & 0,2457 & 0,0081 & 0,3195 & 0,3673 \\
473,0 & 0,0538 & 0,2478 & 0,0072 & 0,3197 & 0,3715 \\
493,0 & 0,0544 & 0,2587 & 0,0076 & 0,3336 & 0,3456 \\
513,0 & 0,0496 & 0,2720 & 0,0084 & 0,3496 & 0,3204 \\
413,0 & 0,0907 & 0,1945 & 0,0030 & 0,2991 & 0,4128 \\
433,0 & 0,0776 & 0,1877 & 0,0077 & 0,2917 & 0,4352 \\
453,0 & 0,0531 & 0,2194 & 0,0076 & 0,3258 & 0,3940 \\
473,0 & 0,0478 & 0,2046 & 0,0073 & 0,3033 & 0,4370 \\
493,0 & 0,0473 & 0,2191 & 0,0127 & 0,3302 & 0,3907 \\
513,0 & 0,0499 & 0,2421 & 0,0142 & 0,3642 & 0,3296 \\
\hline & & & & &
\end{tabular}




\section{HASIL DAN PEMBAHASAN}

Hasil perhitungan ini disajikan pada Gambar 3. Hasil analisis menunjukkan bahwa semakin besar konsentrasi etanol masuk maka semakin besar pula laju reaksi. Hal ini dikarenakan bahwa reaksi dehidrasi etanol merupakan reaksi pelepasan air. Dengan berkurangnya kadar/kandungan air dalam umpan, maka akan dapat menyebabkan fraksi air semakin rendah, sehingga reaksi akan dapat bergeser ke kanan. Bahan baku dengan kadar air yang rendah akan menghasilkan laju reaksi yang lebih.

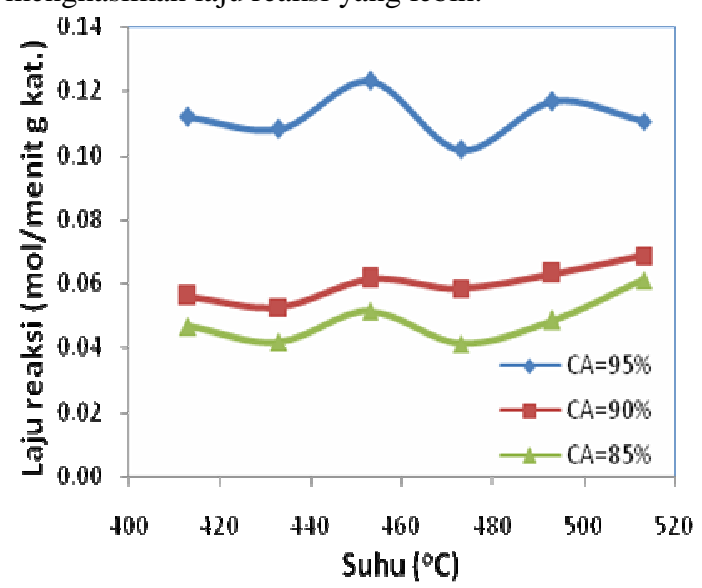

Gambar 3. Grafik hubungan antara suhu dengan laju reaksi pada berbagai konsentrasi umpan

Hasil simulasi kinetika disajikan dalam Tabel 3. Hasil simulasi menunjukkan bahwa model 1 dan model 3 memberikan fungsi obyektif yang nilainya sama, namun berbeda dalam nilai SSE dan koefisien determinasi. Koefisien determinasi menunjukan kotribusi pemodelan. Semakin besar nilai koefisien determinasi maka semakin besar kontribusinya terhadap respon. Adapun SSE merupakan jumlah kwadrat sekitar regresi. Tabel 3 menunjukkan bahwa bahwa model 3 memberikan hasil yang lebih baik ditinjau dari koefisien determinasi dibandingkan dengan model 1 . Model 3 yang merupakan model kinetika dimana proses desorpsi produk mengendalikan reaksi memberikan nilai SSE (Sum Square Error) paling rendah dan koefisien determinasi paling besar. Dengan demikian proses desorpsi produk DiEtil Eter dan etilen merupakan reaksi yang mengendalikan reaksi global, sehingga model kinetika reaksi dehidrasi etanol menjadi DiEtil Eter dan etilen seperti pada Persamaan 29-30.

Nilai energi aktivasi pada model kinetika reaksi diatas adalah untuk pembentukan DiEtil Eter sebesar 30.8691,1 Joule/mol dan pembentukan etilen 31.287,8 Joule/mol. Dengan demikian model kinetika reaksi proses dehidrasi etanol menjadi DiEtil Eter dan etilen pada konsentrasi etanol $85-95 \%$ dan rentang temperatur $140-240^{\circ} \mathrm{C}$ adalah sebagai berikut;

Nilai laju reaksi selanjutnya dibuat grafik yang merupakan hubungan laju reaksi model kinetika dengan laju reaksi dari percobaan. Grafik yang diperoleh, disajikan pada Gambar 4. Gambar 4 menunjukkan bahwa model kurang terlalu valid untuk merepresentasikan proses dehidrasi etanol menjadi DiEtil Eter dan etilen sehingga perlu dilakukan penelitian lebih lanjut tentang hal ini. Untuk mengetahui tingkat akurasi model kinetika, data laju reaksi eksperimen dan laju reaksi model dievalusi nilai \%kesalahan.

Hasil perhitungan $\%$ kesalahan yang terbesar adalah $-30,54 \%$ dan $61,85 \%$, adapun \%kesalahan ratarata sebesar $30,87 \%$. Dengan nilai \% penyimpangan yang diperoleh cukup besar, sehingga pemodelan untuk kinetika reaksi perlu dilakukan penelitian yang lebih detail lagi.

$$
\begin{aligned}
r_{A 1} & =\frac{4,266 e^{-\frac{30.869,1}{R T}} P_{B}}{\left(1+20,756 P_{A}+90,357 P_{B}+115,613 P_{C}+21,088 P_{D}+119,95 P_{I}\right)} \\
r_{A 2} & =\frac{205,3086 e^{-\frac{31.287,8}{R T}}}{\left(1+20,756 P_{A}+90,357 \mathrm{P}_{B}+115,613 \mathrm{P}_{C}+21,088 P_{D}+119,95 P_{I}\right)} P_{D}
\end{aligned}
$$

Tabel 3. Hasil simulasi kinetika reaksi proses dehidrasi etanol

\begin{tabular}{cccccc}
\hline & $\mathrm{k}_{1}$ & \multicolumn{2}{c}{$\mathrm{k}_{2}$} & $\mathrm{~K}_{\mathrm{A}}(1 / \mathrm{atm})$ & $\begin{array}{c}\mathrm{K}_{\mathrm{B}} \\
(1 / \mathrm{atm})\end{array}$ \\
\cline { 1 - 4 } $\mathrm{A}$ & $\mathrm{E}_{\mathrm{A} 1}(\mathrm{~J} / \mathrm{mol})$ & $\mathrm{A}$ & $\begin{array}{c}\mathrm{E}_{\mathrm{A} 2} \\
(\mathrm{~J} / \mathrm{mol})\end{array}$ & & \\
\hline 0,411 & 30.800 & 1,789 & $5.304,1$ & 4,1789 & 26,1804 \\
0,019 & 30.800 & 1,869 & $5.327,0$ & 3,5874 & 25,2991 \\
2,133 & $30.869,1$ & 9,723 & $31.287,8$ & 20,756 & 90,357 \\
\hline
\end{tabular}

\begin{tabular}{ccccccc}
\hline $\begin{array}{c}\mathrm{K}_{\mathrm{C}} \\
(1 / \mathrm{atm})\end{array}$ & $\begin{array}{c}\mathrm{K}_{\mathrm{D}} \\
(1 / \mathrm{atm})\end{array}$ & $\begin{array}{c}\mathrm{K}_{\mathrm{I}} \\
(1 / \mathrm{atm})\end{array}$ & $\mathrm{F}(\mathrm{x})$ & $\begin{array}{c}\text { SSE } \\
(\text { Sum Square } \\
\text { Error })\end{array}$ & $\begin{array}{c}\text { Koefisien } \\
\text { determinasi } \\
\left(\mathrm{R}^{2}\right)\end{array}$ & Keterangan \\
\hline 23,9455 & 1.4955 & 32,1757 & 0,0133 & $6,83510^{-5}$ & 0,8512 & Model 1 \\
24,3801 & 1,4124 & 26,9798 & 0,0147 & 0,013 & $-1,0605$ & Model 2 \\
115,613 & 21,088 & 119,95 & 0,0133 & $5,22910^{-5}$ & 0,8698 & Model 3 \\
\hline
\end{tabular}




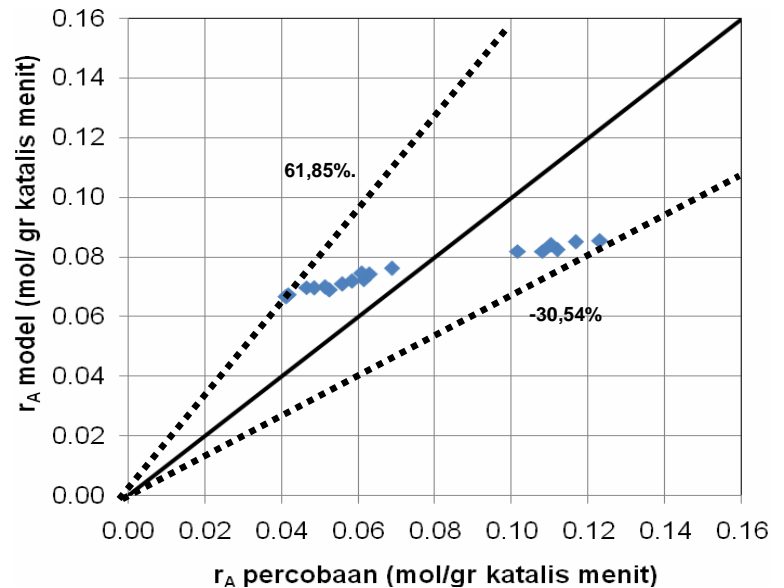

Gambar 4. Hasil validasi laju reaksi dehidrasi etanol model 3 dengan hasil percobaan

\section{KESIMPULAN}

Berdasarkan hasil penelitian dapat diambil kesimpulan bahwa konversi etanol meningkat dengan peningkatan temperatur pada rentang temperatur $120-240^{\circ} \mathrm{C}$ dimana konversi etanol terbesar $87,45 \%$ pada konsentrasi umpan etanol $95 \%$ dan temperatur $240^{\circ} \mathrm{C}$. Model kinetika reaksi proses dehidrasi etanol menjadi DiEtil Eter dan etilen dengan katalis H-zeolit pada konsentrasi umpan etanol $85-95 \%$ dan rentang temperatur $140-240^{\circ} \mathrm{C}$, dimana reaksi desorpsi produk DiEtil Eter dan etilen yang mengontrol reaksi global adalah sebagai berikut;

$\mathrm{r}_{\mathrm{A} 1}=\frac{4,266 \mathrm{e}^{-\frac{30.869,1}{R T}} \mathrm{P}_{\mathrm{B}}}{\left(1+20,756 \mathrm{P}_{\mathrm{A}}+90,357 \mathrm{P}_{\mathrm{B}}+115,613 \mathrm{P}_{\mathrm{C}}+21,088 \mathrm{P}_{\mathrm{D}}+119,95 \mathrm{P}_{\mathrm{I}}\right)}$
$\mathrm{r}_{\mathrm{A} 2}=\frac{205,3086 \mathrm{e}^{-\frac{31.287 .8}{R T}}}{\left(1+20,756 \mathrm{P}_{\mathrm{A}}+90,357 \mathrm{P}_{\mathrm{B}}+115,613 \mathrm{P}_{\mathrm{C}}+21,088 \mathrm{P}_{\mathrm{D}}+119,95 \mathrm{P}_{\mathrm{I}}\right)} \mathrm{P}_{\mathrm{D}}$

Model kinetika reaksi mempunyai \% kesalahan yang terbesar adalah $-30,54 \%$ dan $61,85 \%$, adapun \%kesalahan rata-rata sebesar $30,87 \%$.

\section{DAFTAR NOTASI}

\begin{tabular}{|c|c|}
\hline$C_{A}$ & Konsentrasi etanol \\
\hline$C_{A S}, C_{B S}$ & Luas permukaan yang \\
\hline $\begin{array}{l}C_{C S}, C_{D S} \\
\text { dan } C_{I S}\end{array}$ & $\begin{array}{l}\text { ditempati oleh senyawa- } \\
\text { senyawa A, B, C, D dan I } \\
\text { yang teradsorpsi pada } \\
\text { permukaan katalis }\end{array}$ \\
\hline$C_{S}$ & $\begin{array}{l}\text { Luas permukaan kosong } \\
\text { pada katalis }\end{array}$ \\
\hline$C_{T}$ & $\begin{array}{l}\text { Fraksi luas permukaan aktif } \\
\text { total pada katalis }\end{array}$ \\
\hline$D E E$ & DiEtil Eter \\
\hline$E_{A}$ & Energi aktifasi \\
\hline$F_{A o}$ & Laju alir etanol masuk \\
\hline$F_{A}$ & Laju alir etanol keluar \\
\hline $\mathrm{HCl}$ & Asam klorida \\
\hline
\end{tabular}

(b/b) $\mathrm{cm}^{2}$

$\begin{array}{ll} & -r_{A 2} \\ & \\ & R \\ \mathrm{~cm}^{2} & S \\ & S i / A\end{array}$

$\mathrm{Si} / \mathrm{Al}$

STA

$T$

Joule/mol $\mathrm{mol} / \mathrm{menit}$ $\mathrm{mol} / \mathrm{menit}$

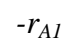

$-r^{-1}$

$r_{A 2}$

i/Al

W

$x_{A}$
$k_{A}$

$k_{A}^{\prime}$

$k_{B}$

$k_{B}^{\prime}$

$k_{C}$

$k_{C}^{\prime}$

$k_{D}$

$k_{D}^{\prime}$

$k_{I}$

$k_{I}^{\prime}$

$k_{1}, k_{2}$,

$k_{A A}, k_{A 2}$,

$k_{B B}, k_{D}^{\prime}$

K

$K_{A}$

$K_{B}$

$K_{C}$

$K_{D}$

$K_{I}$

P

$P_{0}$

$P A$
Konstanta laju adsorpsi komponen A (etanol) Konstanta laju desorpsi komponen A (etanol)

Konstanta laju adsorpsi komponen B (DEE)

Konstanta laju desorpsi komponen B (DEE)

Konstanta laju adsorpsi komponen C (air)

Konstanta laju desorpsi komponen C (air)

Konstanta laju adsorpsi komponen A (etilen) Konstanta laju desorpsi komponen A (etilen) Konstanta laju adsorpsi komponen I (nitrogen) Konstanta laju desorpsi komponen I (nitrogen) Konstanta laju reaksi kimia untuk reaksi dehidrasi etanol menjadi DEE dan etilen

\section{Konstanta kesetimbangan} Konstanta kesetimbangan adsorpsi-desorpsi

komponen etanol

Konstanta kesetimbangan adsorpsi-desorpsi

komponen DEE

Konstanta kesetimbangan adsorpsi-desorpsi

komponen air

Konstanta kesetimbangan adsorpsi-desorpsi komponen etilen

Konstanta kesetimbangan adsorpsi-desorpsi komponen inert

$$
\text { tekanan }
$$

Tekanan keadaan standart

Pro analysis spesifikasi

bahan kimia untuk keperluan analisa

Laju reaksi pembentukan DiEtil Eter

Laju reaksi pembentukan etilen

Konstanta gas

Sisi aktif pada katalis padat perbandingan berat silika dan alumina

Silicotungstic acid

Temperatur

Berat katalis

konversi etanol $\mathrm{s} / \mathrm{m}^{2} \mathrm{~mol}$

$\mathrm{s} / \mathrm{m}^{2} \mathrm{~mol}$

$\mathrm{s} / \mathrm{m}^{2} \mathrm{~mol}$

$\mathrm{s} / \mathrm{m}^{2} \mathrm{~mol}$

$\mathrm{s} / \mathrm{m}^{2} \mathrm{~mol}$

$\mathrm{s} / \mathrm{m}^{2} \mathrm{~mol}$

$\mathrm{s} / \mathrm{m}^{2} \mathrm{~mol}$

$\mathrm{s} / \mathrm{m}^{2} \mathrm{~mol}$

$\mathrm{s} / \mathrm{m}^{2} \mathrm{~mol}$

$\mathrm{s} / \mathrm{m}^{2} \mathrm{~mol}$

$\left(\mathrm{m}^{3}\right)^{\mathrm{n}} / \mathrm{mol}^{\mathrm{n}-1}$

gr kat menit

1/atm

1/atm

1/atm

1/atm

1/atm

atm

atm

$\mathrm{Mol} /$ menit gr katalis

$\mathrm{Mol} /$ menit gr katalis $\mathrm{J} / \mathrm{mol} \mathrm{K}$ ${ }^{\circ} \mathrm{C}$ gram $\%$ 


\section{DAFTAR PUSTAKA}

Boveri, M., Ma'rquez-A' lvarez, C., Laborde, M.A., and Sastre, E., (2006), Steam And Acid Dealumination Of Mordenite Characterization And Influence On The Catalytic Performance In Linear Alkylbenzene Synthesis, Catalysis Today, pp. 217255.

De Boer, J.H., Fahim, R.B., GLinsen, B., Vissere, W.J., and deVlesschauwer, W.F.N.M., (1967), Kinetics of the Dehydration of Alcohol on Alumina, Journal of Catalysis, 7, pp.163-172.

Fogler, S.H., (1999), Elements of Chemical Reaction Engineering, University of Michigan, USA.

Golay, S., Kiwi-Minsker, L., Doepper, R., and Renken, A., (1999), Influence of the catalyst acid/base properties on the catalytic etanol dehydration under steady state and dynamic conditions. In situ surface and gas-phase analysis, Chemical Engineering Science, 54, pp. 3593-3598.

Haber, J., Pamin, K., Matachowski, L., Napruszewska, B., and Poltowicz, J., (2002), Potassium and Silver Salts of Tungstophosphoric Acid as Catalysts in Dehydration of Etanol and Catalysis Letters Hydration of Ethylene, Journal of Catalysis, 207, pp. 296-306.

Kito-Borsa T, DA. Pacas, S Selim, and SW. Cowley, (1998), Properties of an Etanol-Diethyl Ether-Water Fuel Mixture for Cold-Start Assistance of an EtanolFueled Vehicle, Ind. Eng. Chem. Res., 37, pp. 33663374.

Rachwalik, R., Olejniczak, Z., and Sulikowski, B., (2005), Dealumination of ferrierite type zeolite: Physicochemical and catalytic properties, Catalysis Today, 101, pp.147-154.
Takahara, I., Saito, M., Inaba, M., and Murata, K., (2005), Dehydration of etanol into ethylene over solid acid catalysts, Vol 105, pp. 249-252.

Ullmann, (1987), Encyclopedia of Industrial Chemistry, Vol. A.10, $5^{\text {th }}$ edition, VCH Verlagsgesellschaft, Weinhem Federal Republic of Germany.

Varisli, D., Dogu, T., and Dogu, G., (2007), Ethylene and diethyl-ether production by dehydration reaction of etanol over different heteropolyacid catalysts, Chem Eng Sci, 62, pp.5349-5352.

Widayat dan Satriadi, H., (2008), Optimasi Pembuatan Dietil eter dengan Proses Reaktif Distilasi, Jurnal Reaktor, 12 (1), hal. 7-11.

Widayat, Roesyadi, A., dan Rachimoellah, M., (2009), The Effect of Time dealumination and Solvent Concentration in Synthesis of Zeolite Catalyst and Catalytic Test for DiEthyl Ether Production Process, AIP Conference proceeding 1169 Internation Workshop on Advanced Material for New and Renewable Energy, Jakarta.

Widayat, Roesyadi, A., dan Rachimoellah, M., (2010), Pengaruh Waktu Dealuminasi dan Jenis Sumber Zeolit Alam Terhadap Kinerja H-Zeolit untuk Proses Dehidrasi Etanol, Jurnal Reaktor, 13 (1), hal. 51-57.

Widayat, Roesyadi, A., dan Rachimoellah, M., (2011), The Effect of Temperature and Ethanol Concentration on Diethyl Ether Production By Using Adsorption-Dehydration Process, International Review of Chemical Engineering Journal, Vol. 3 No. 1, pp. 87-92.

Zablouka, M.A., Kaseera, N.W., Hadi, G.J., and Hadi, A.J., (2011), Comparison the Performance of Four Catalyst Types in the Calytic Dehaydration of Ethano, Journal of Advanced Science and Engineering Research, 1, pp. 137-149. 